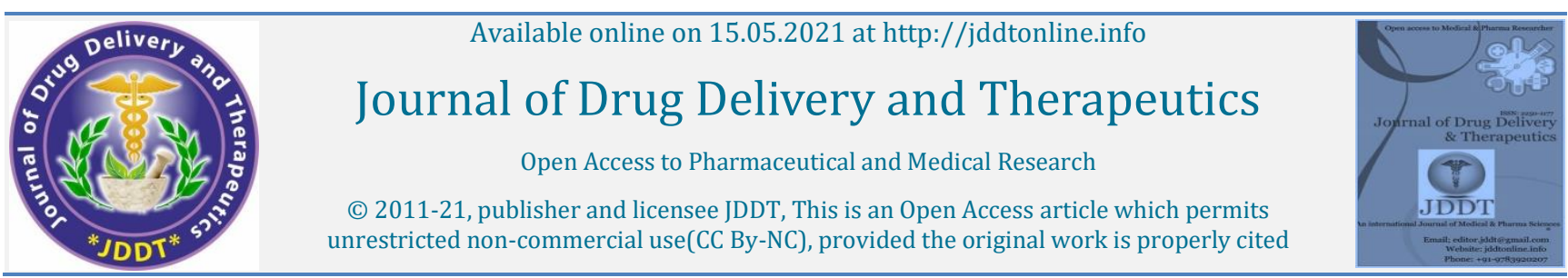

(C) 2011-21, publisher and licensee JDDT, This is an Open Access article which permits
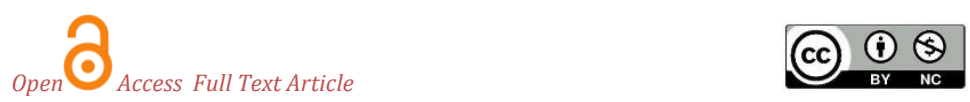

Review Article

\title{
Significance of Ahara Vidhi Vidhana in COVID -19 Pandemic
}

\author{
Ramakant Dwivedi ${ }^{*}$, Jayashankar Mund², Amit Vishvas Nakanekar ${ }^{3}$ \\ ${ }^{1}$ PhD. Scholar, Mandsaur Institute of Ayurved Education \& Research Mandsaur, India \\ ${ }^{2}$ Professor \& HOD Department of Basic Principles Mandsaur Institute of Ayurved Education \& Research Mandsaur, India \\ ${ }^{3}$ Assistant Professor Kaya Chikitsa Dept Govt Ayurvedic college Nagpur, India
}

\section{Article Info:}

$\begin{array}{ll}\text { Article History: } & \text { Received 22 March 2021; } \\ \text { Review Completed 27 April } 2021 & \text { Accepted 03 May 2021; } \\ \text { Available online 15 May } 2021\end{array}$

Cite this article as:

Dwivedi R, Mund J, Nakanekar AV, Significance of Ahara Vidhi Vidhana in COVID -19 Pandemic, Journal of Drug Delivery and Therapeutics. 2021; 11(3):160-162 DOI: http://dx.doi.org/10.22270/jddt.v11i3.4797

*Address for Correspondence:

Dr. Ramakant Dwivedi, PhD. Scholar, Mandsaur Institute of Ayurved Education \& Research Mandsaur, India

\section{Abstract}

The emergence of COVID -19 pandemic has impacted individuals in each and every field of life. The rapid spread of the disease to nearly all parts of the country has posed enormous health, economic, environmental and social challenges to the entire human population. In the absence of any effective drugs and vaccines for treatment, social distancing and Wearing mask are important measures. But these measures were not followed properly so Lockdown was among one of the options suggested by World Health Organization (WHO) to reduce spread of the virus. On March 22, 2020 In India world's largest COVID lockdown came into existence. In this lockdown there was a kind of fear different theories of virus spread were in existence. So People have to change their life style. Cinema hall, resurents were closed online food delivery system was also under suspicion so it was a question how to adopt healthy food habit and keep healthy to himself . In this critical time application of ayurvedic principles and follow them properly was a heat of hope

Keywords: COVID, lockdown, mask.

\section{INTRODUCTION:}

Since the the time of eternity Ayurveda is serving the mankind. The main aim of Ayurveda is to preserve health of healthy person, and to treat the disease of a diseased one. ${ }^{1}$ For this we have to follow some rules called as the Trayopasthambas $^{2}$ (Three sub pillars) of life i.e.- Ahara (Food), Nidra (Sleep), and Brahmacharya (Celibacy). Ahara ${ }^{3}$ is considered as life of all the living beings. In present era altered habits of diet and lifestyle may leads to various diseases. This is very crucial time so Some dietic rules and regulations explained in Ayurveda, which are considered as Ahara vidhi vidhanas (Rules for taking food).If Ahara vidhi vidhanas is followed properly, it helps to maintain the health and increase life span. ${ }^{4}$ In shushrut Samhita food is said to be base of life. Rules of taking food have similar importance as food. So proper food and proper intake of food will help to reduce the risk of some other diseases like heart disease, diabetes, stroke, osteoporosis, blood pressure etc. Adequate and appropriate nutrition is required for all cells to function optimally and this includes the cells in the immune system. An "activated" immune system further increases the demand for energy during periods of infection, with greater basal energy expenditure during fever for example. Thus, optimal nutrition for the best immunological outcomes would be nutrition, which supports the functions of immune cells allowing them to initiate effective responses against pathogens but also to resolve the response rapidly when necessary and to avoid any underlying chronic inflammation. The immune system's demands for energy and nutrients can be met from exogenous sources i.e., the diet, or if dietary sources are inadequate, from endogenous sources such as body stores. ${ }^{5}$

\section{AHARA VIDHI VIDHANA (Rules for taking food)}

Ahara means food, Vidhi means method of accomplishing. A few rules should be methodically accomplished. These are the methods which should be observed for while taking food are one should eat hot, unctuous food, food stuff with opposite veerya (potency) should not be eaten together. And one should eat in pleasant place, with pleasant utensils. One should not eat very fast or very slow. One should not laugh or talk while eating. One should eat whole mindedly. One should pay attention to himself while eating. ${ }^{6}$

\section{1) USHNAM ASHNIYAT (Food should be warm))}

Ushnam Ashniyat means, a person should eat warm food and freshly prepared food. The first requirement regarding preparation of meal is that it should be Ushna (hot). Ushna food is pleasant means it is good in tastes and increases appetite as well as secretions of digestive juices, such food gets digested fast. It does proper functioning of vata and deceases the Kapha Dosha ${ }^{7}$

Ayurveda also recommends that one should drink warm water, as Warm water stimulates hunger and digestive fire, helps in digestion it sooths throat, cleanses the bladder 
,reduces hiccups, it removes Ama (the metabolic toxin) of body. Warm water is best in winter and for those foods which are difficult to digested. ${ }^{8}$

It has also explained in Ayurvedic text that a person should not take sheeta anna. If cooked food left for long time and taken causes Aruchi (loss of taste), Agnimandhya (weak digestive power), vistamba, Romaharsha (Horripilation), Stambana (stiffness) etc. The virus that causes COVID-19 can be killed at temperatures similar to that of other known viruses and bacteria found in food. Foods such as meat, poultry and eggs should always be thoroughly cooked to at least $70^{\circ} \mathrm{C}$. Before cooking, raw animal products should be handled with care to avoid cross-contamination with cooked foods. ${ }^{9}$

\section{2) SNIGDHAM ASHNIYAT (Food should be unctuous) -}

After ushna bhojana there is rule is to eat snigdha ahara. It enhances the weak Agni. Sneha digests the food quickly. It also helps for vatanulomana, it replenishes or nourishes the body. It increases the body strength. This is the reason why one should eat snigdha ahara. Snigdha dravya promotes the first avasthapaka and increases bala and which rejuvenate the body by decreasing thespeed of ageing process (jara). 10

Over the last 30 years, the literature has described a definitive role of fat in immunity. Saturated fatty acids act on Toll-like receptor 4 , a sensor that binds bacterial lipopolysaccharide and thus acts in the innate immune response. As a result, a high intake of saturated fatty acids favors low-grade inflammation. On the other hand, monounsaturated and polyunsaturated fatty acids are known for their favorable immune-modulatory action. Omega-3 polyunsaturated fatty acids present in seafood, algal oil, marine fish, and flaxseed support the immune system by activating cells from both the innate and the adaptive immune systems, while omega-9 monounsaturated fatty acids found in olive, sunflower, and safflower oils and nuts have antioxidant, antimicrobial, and antiviral effects. ${ }^{11}$

\section{3) MATRAVAT ASHNIYAT (Food in proper quantity)}

It means one should eat adequate amount. For proper maintenance of positive health one should eat in proper quantity. The quantity of food to be taken again depends upon the power of digestion ${ }^{12}$. The amount of food which, without disturbing the equilibrium of doshas and dhatus of the body, gets digested as well as metabolized in proper time, is to be regarded as the proper time. It should not be eaten in excess or in less amounts. Such food maintains physiological level of dosha vata, pitta, and kapha. It passes excreta smoothly, and digestion will be perfect. The symptoms of appropriate Matra (quantity) are there should no undue pressure on stomach, no pressure in the flanks and no interference in the proper functioning of heart and no excessive heaviness of abdomen. It does proper nourishments of the senses, relief from hunger and thirst, feel of comfort in all the functions like standing, sleeping, walking and talking. 13

If it is taken in excess amount can cause obesity. Although there is some lack of clarity and guidance regarding obesity as a risk factor for COVID-19, substantial preliminary data demonstrate that higher body mass index is a considerable risk factor for hospitalization and development of severe pneumonia. ${ }^{14}$

\section{4) JIRNE ASHNIYAT (Intake after digestion of previous meal)}

Intake of food should only when previous meal is digested. If food is taken before the digestion of previous meal, food to be digested gets mixed with food which is half digested which leads to vitiation of three doshas. If eaten when previous food is digested, all the three doshas remain in physiological limits, agni is enhanced no pressure on heart is realized, excreta is smoothly expelled all body tissues are well maintained and there by lifespan is increased.15

\section{5) VIRYA AVIRUDDHA ASHNIYAT (Intake of food having no contradictory potencies)}

Virya (Potency) is the power of substance by which action takes place. The opposite strong qualities should be avoided to eat together. Eat those food which are not antagonist in virya .Such opposite quality of food generate various diseases. ${ }^{16}$

\section{6) ISHTA DESHE / ISTHA SARVOPAKARANAMASHNIYAT (Intake in proper place and with all accessories)}

A person should not eat on unfavorable place. The place should be hygienic, and should not produce disturbing emotions like Kama (Desire), Krodha (Anger), Cinta (Stress), Bhaya (Fear), Vishada (Depression) etc. All these factors influence the psyche as well as hygiene of the place. So it is very obvious that for healthy food healthy surrounding is required. ${ }^{17}$ In this covid era WHO has also some recommendation which are to avoid cross-contamination between cooked and uncooked foods, including, as mentioned, cooking meat thoroughly and others (e.g., washing hands.) ${ }^{18}$

\section{7) NAATIDRUTAM ASHNIYAT (Intake, not in hurry) 19}

One should not eat very fast. If food is taken very fastly it enters into wrong pathway and will not be placed properly. If one eats very fast, he chokes, vomits, insults food and develops disliking speed of ageing process (jara). This is the reason why one should not eat fast. Fast eating is associated with excess body weight and reducing rate of eating appears to reduce energy intake.

\section{8) NAATIVILAMBITASHNIYAT ${ }^{20}$ (Intake, not too slow)}

One should not eat very slowly. If one eats very slowly, does not get satiety hence eats more and food gets cold. All these factors hamper Agni and the food is not digested propely8. So one should not eat very slowly. Kalpan et al produced that over eating can cause obesity whichis developed by slow eating. ${ }^{21}$

\section{9) AJALPAN, AHASAN, TANMANABHUNJITAM ${ }^{22}$ (Intake with concentration)}

One should not talk or laugh while eating. This vitiates the doshas. If one talks or laughs while eating is liable to suffer from the same disorders as the one who eats too fast. In this most important is that food is eaten with full of concentration8 8 This is the reason one should not talk or laugh while eating.

10) AATMANAMABHISAMIKSHYA BHUNJITAM 23 (Eating after analyzing one's needs) -One should eat for self with appropriate manner. One should think while eating which is suitable for self and which is not suitable for self. This makes oneself to eat properly. 


\section{DISCUSSION}

Ahara, Nidra and Brahmacharya are three sub pillars of life. Ahara plays an important role in the promotion of health and prevention of disease. Along with the quality and quantity if we concentrate on the right way of taking food and the regimens related to ahara described in Ayurveda, we can achieve positive health easily. Improper diet habit (Frozen, canned and processed) is primary reason for increasing the health disorders. In today's life we are more interested in eating tasty, and eat more of junk foods and we will not concentrate on healthy food. Nobody is concentrating on rules of dieting and right way of eating. So there is a need to aware the people about the importance of food and methods of intake. At present much newer food processing methods are in practice, these methods bring chemical as well as physical changes. They definitely improve the appearance, taste, flavor, shelf life and preservation of food but not good for health.

In present era due to lack of knowledge, negligence, lack of time and also people are not following the prescribed rules for preparing, preserving, and eating food, suffering from various life style disorders. These life style disorders are avoided by following various regimens described in our Ayurvedic samhita. By seeing the above points, it can be concluded that Ahara should be taken according to Ahara vidhi vidhana and which are truly scientific by our acharyas. Ahara vidhi vidhanas are very beneficial in present lifestyle.

\section{CONCLUSION}

Ayurveda has explained so many valuable thoughts. Food is the most essential part of life. Diet and method of food intake has an important role in maintaining of health and prevention of diseases. In today's fast life we are more interested in eating tasty food materials and we are not following proper dietary habits and following wrong food habits which all are the primary causes for health disorders. Ahara vidhi vidhanas are method of eating which is equally important as food. Health is mainly depending upon food and right way of taking food. Proper food will maintain health and treat the various health disorders and that's why food is called as Mahabhaishajya. An ideal food not only nourishes the body, but also nourishes the mind. Hence the type of food we consume influences qualities of life. It may impact directly or indirectly upon immune cells causing changes in their function or may exert effects via changes in the gut microbiome. A better understanding of the role of nutrients in immune function will facilitate the use of bespoke nutrition to improve human health 24 .

\section{REFERENCES}

1-Charaka Samhita by Agnivesa with Vidyotni hindi commentary Kashinath shastri gorakhnath chaturvedi ,Chaukhamba bharati Acedmy Prakashana; Reprint 2008 Ch.vi 30/26.p.683

2- Charaka Samhita by Agnivesa with Vidyotni hindi commentary Kashinath shastri gorakhnath chaturvedi ,Chaukhamba bharati Acedmy Prakashana; Reprint 2008 Ch.Su 1 1/35.p.227 .

3- Charaka Samhita by Agnivesa with Vidyotni hindi commentary Kashinath shastri gorakhnath chaturvedi ,Chaukhamba bharati Acedmy Prakashana; Reprint 2008 Ch.Su 7/3.p.525.
4) Charaka Samhita by Agnivesa with Vidyotni hindi commentary Kashinath shastri gorakhnath chaturvedi ,Chaukhamba bharati Acedmy Prakashana; Reprint 2008 Ch.vi 1/24.p.683

5- Shushruta Samhita By Maharshi shushrut , Tatvasandipika Hindi commentary by Kaviraj Ambika Datta Shastri Chaukhambha Sanskrit Sansthan Reprint 2008 Su46/3 Page 187. \& https://www.ncbi.nlm.nih.gov/pmc/articles/PMC6723551/ Diet and Immune Function

6) Charaka Samhita by Agnivesa with Vidyotni hindi commentary Kashinath shastri gorakhnath chaturvedi ,Chaukhamba bharati Acedmy Prakashana; Reprint 2008 Ch.vi 1/24.p.683

7) Charaka Samhita by Agnivesa with Vidyotni hindi commentary Kashinath shastri gorakhnath chaturvedi ,Chaukhamba bharati Acedmy Prakashana; Reprint 2008 Ch.vi 1/24-1-.p.683.

8) Kunte AM.Astanga Hrudaya of Vagbhata. Varanasi: Chaukhamba Sanskrit Sansthana; Reprint 2012.65 \&

9-https://www.who.int/news-room/q-a-detail/coronavirusdisease-covid-19-food-safety-and-nutrition.

10-) Charaka Samhita by Agnivesa with Vidyotni hindi commentary Kashinath shastri gorakhnath chaturvedi ,Chaukhamba bharati Acedmy Prakashana; Reprint 2008 Ch.vi 1/24-2-.p.683.

11- Ruiz-Nuñez B, Dijck-Brouwer DAJ, Muskiet FAJ.. The relation of saturated fatty acids with low-grade inflammation and cardiovascular disease. J Nutr Biochem. 2016;36:1-20.

12- Charaka Samhita by Agnivesa with Vidyotni hindi commentary Kashinath shastri gorakhnath chaturvedi ,Chaukhamba bharati Acedmy Prakashana; Reprint 2008 Ch.vi 1/24-3-.p.684.

13- Charaka Samhita by Agnivesa with Vidyotni hindi commentary Kashinath shastri gorakhnath chaturvedi ,Chaukhamba bharati Acedmy Prakashana; Reprint 2008 Ch.Su 5/3-4.p.103.

14--Flint SW, Tahrani AA. COVID-19 and obesity-lack of clarity, guidance, and implications for care. Lancet Diabetes Endocrinol.2020;8:474-475. doi:10.1016\%2FS22138587(20)30156-X

15-) Charaka Samhita by Agnivesa with Vidyotni hindi commentary Kashinath shastri gorakhnath chaturvedi ,Chaukhamba bharati Acedmy Prakashana; Reprint 2008 Ch.vi 1/24-4-.p.684.

16- Charaka Samhita by Agnivesa with Vidyotni hindi commentary Kashinath shastri gorakhnath chaturvedi ,Chaukhamba bharati Acedmy Prakashana; Reprint 2008 Ch.vi 1/24-5-.p.684.

17- Charaka Samhita by Agnivesa with Vidyotni hindi commentary Kashinath shastri gorakhnath chaturvedi ,Chaukhamba bharati Acedmy Prakashana; Reprint 2008 Ch.vi 1/24-6-.p.684.

18--No Evidence of COVID-19 Transmission through Food, Says EFSA - EURACTIV.com. Available online:

https://www.euractiv.com/section/coronavirus/news/noevidence-of-covid-19-transmission-throughfood-says-efsa/ (accessed on 13 April 2020).\&

https://www.researchgate.net/publication/11040898_Food_an d_emotion.

19- Charaka Samhita by Agnivesa with Vidyotni hindi commentary Kashinath shastri gorakhnath chaturvedi ,Chaukhamba bharati Acedmy Prakashana; Reprint 2008 Ch.vi 1/24-7-.p.685.

20-- Charaka Samhita by Agnivesa with Vidyotni hindi commentary Kashinath shastri gorakhnath chaturvedi ,Chaukhamba bharati Acedmy Prakashana; Reprint 2008 Ch.vi 1/24-8-.p.685

21- Ohkuma T., Hirakawa Y., Nakamura U., Kiyohara Y., Kitazono T., Ninomiya T. Association between eating rate and obesity: A systematic review and meta-analysis. Int. J. Obes. (Lond.) 2015;39:1589-1596. doi: 10.1038/ijo.2015.96.

22--- Charaka Samhita by Agnivesa with Vidyotni hindi commentary Kashinath shastri gorakhnath chaturvedi ,Chaukhamba bharati Acedmy Prakashana; Reprint 2008 Ch.vi 1/24-9-.p.685

23- Charaka Samhita by Agnivesa with Vidyotni hindi commentary Kashinath shastri gorakhnath chaturvedi ,Chaukhamba bharati Acedmy Prakashana; Reprint 2008 Ch.vi 1/24-9-.p.685.

24-Childs CE, Calder FC, Miles EA, Diet and Immune Function, Nutrients. 2019 Aug 16; 11(8):1933. doi: 10.3390/nu11081933 